Research

Open Access

\title{
Surfactant therapy for acute respiratory failure in children: a systematic review and meta-analysis
}

Mark Duffett ${ }^{1}$, Karen Choong ${ }^{1}$, Vivian $\mathrm{Ng}^{2}$, Adrienne Randolph ${ }^{3}$ and Deborah J Cook ${ }^{4}$

\author{
1Department of Critical Care, McMaster Children's Hospital, 1200 Main St. W., Hamilton, Ontario L8S 4J9, Canada \\ ${ }^{2}$ Grand River Hospital, 835 King St. West, Kitchener, Ontario N2G 1G3, Canada \\ ${ }^{3}$ Children's Hospital Boston, 300 Longwood Avenue, MSICU, FA-108, Boston, MA 02115, USA \\ ${ }^{4}$ Department of Clinical Epidemiology and Statistics, McMaster University, 1200 Main St. W., Hamilton, Ontario L8N 3Z5, Canada \\ Corresponding author: Mark Duffett, duffett@hhsc.ca
}

Received: 16 Mar 2007 Revisions requested: 13 Apr 2007 Revisions received: 11 May 2007 Accepted: 15 Jun 2007 Published: 15 Jun 2007

Critical Care 2007, 11:R66 (doi:10.1186/cc5944)

This article is online at: http://ccforum.com/content/11/3/R66

(C) 2007 Duffett et al., licensee BioMed Central Ltd.

This is an open access article distributed under the terms of the Creative Commons Attribution License (http://creativecommons.org/licenses/by/2.0), which permits unrestricted use, distribution, and reproduction in any medium, provided the original work is properly cited.

\begin{abstract}
Introduction Exogenous surfactant is used to treat acute respiratory failure in children, although the benefits and harms in this setting are not clear. The objective of the present systematic review is to assess the effect of exogenous pulmonary surfactant on all-cause mortality in children mechanically ventilated for acute respiratory failure.

Methods We searched the MEDLINE, EMBASE, CINAHL and Ovid Healthstar databases, the bibliographies of included trials and review articles, conference proceedings and trial registries. We included prospective, randomized, controlled trials of pulmonary surfactant that enrolled intubated and mechanically ventilated children with acute respiratory failure. We excluded trials that exclusively enrolled neonates or patients with asthma. Two reviewers independently rated trials for inclusion, extracted data and assessed the methodologic quality. We quantitatively
\end{abstract}

pooled the results of trials, where suitable, using a random effects model.

Results Six trials randomizing 314 patients were included. Surfactant use reduced mortality (relative risk $=0.7,95 \%$ confidence interval $=0.4$ to $0.97, P=0.04$ ), was associated with increased ventilator-free days (weighted mean difference $=$ 2.5 days, $95 \%$ confidence interval $=0.3$ to 4.6 days, $P=0.02$ ) and reduced the duration of ventilation (weighted mean difference $=2.3$ days, $95 \%$ confidence interval $=0.1$ to 4.4 days, $P=0.04$ ).

Conclusion Surfactant use decreased mortality, was associated with more ventilator-free days and reduced the duration of ventilation. No serious adverse events were reported.

\section{Introduction}

Acute respiratory failure remains the primary indication for admission to North American paediatric intensive care units (PICUs) and accounts for significant mortality, morbidity and resource utilization [1]. Respiratory infections, in particular pneumonia and severe bronchiolitis, are the most common causes of respiratory failure requiring mechanical ventilation in children [1].

Alterations in endogenous surfactant play a role in the pathogenesis of many causes of acute lung injury (ALI) and acute respiratory distress syndrome (ARDS) [2]. Surfactant dysfunction, destruction and inactivation have also been demonstrated in children with acute respiratory insufficiency due to bronchiolitis $[3,4]$. The administration of exogenous surfactant may reduce the need for mechanical ventilation and its associated sequelae by restoring surfactant levels and function. Inspired by the success of surfactants in reducing mortality and the need for mechanical ventilation in neonatal respiratory distress syndrome [5], investigators have studied exogenous surfactant in other populations with various causes of respiratory failure. Trials of surfactant in adults with ALI and ARDS have not demonstrated a mortality benefit [6-9], perhaps due to inherent differences in the aetiology of lung injury in adults, the design features of the trials, the mode and timing of surfactant administration or the type and dose of surfactant used. In children with respiratory failure, the efficacy of exogenous surfactant has been suggested in uncontrolled studies

$\mathrm{ALI}=$ acute lung injury; $\mathrm{ARDS}=$ acute respiratory distress syndrome; $\mathrm{FiO}_{2}=$ fractional inspired oxygen; $\mathrm{PaO}_{2}=$ arterial oxygen tension; $\mathrm{PICU}=$ paediatric intensive care unit; RSV = respiratory syncytial virus. 
$[10,11]$. The relatively low mortality rate, the diversity of the study populations and the shorter duration of mechanical ventilation are factors that make large-scale randomized controlled trials in this population challenging to conduct. Two of the largest trials were stopped early due to slower than expected enrolment [12,13]. While the use of surfactant in ARDS/ALI has not been previously systematically reviewed, its use in children with bronchiolitis has been [14].

We anticipated that including trials enrolling children with acute respiratory failure from a variety of causes would result in a heterogeneous population and would increase the generalizability of the results. Our confidence in the results of the present review would also be increased if a consistent effect is shown in subgroups and across a spectrum of disease severity.

The primary objective of the systematic review is to assess the effect of the administration of pulmonary surfactant compared with no therapy or with placebo on all-cause mortality (at or before hospital discharge) in mechanically ventilated children with acute respiratory failure.

\section{Methods \\ Trial selection}

We included trials that were prospective, that were randomized, that enrolled children intubated and mechanically ventilated for acute respiratory failure and that compared the intratracheal administration or nebulization of at least one dose of natural or artificial pulmonary surfactant with a placebo or no intervention. We excluded trials exclusively enrolling neonates or patients with asthma. We used the trial authors' definitions of paediatric.

\section{Outcome measures}

The primary outcome measure was all-cause mortality at or before hospital discharge. Secondary outcomes were ventilator-free days to day 28 (a composite of mortality and duration of ventilation, defined as days alive and free from mechanical ventilation) [15], the duration of mechanical ventilation (from intubation to extubation, death or trial withdrawal), the duration of PICU stay, the use of rescue therapy (such as extracorporeal membrane oxygenation, high-frequency oscillatory ventilation, open label surfactant and nitric oxide), and complications and adverse effects as reported by the trial authors.

\section{Searching}

One of us searched for published and unpublished trials, examining trial registries, conference proceedings and the bibliographies of any identified trials and relevant reviews (the search strategy is available upon request). We polled paediatric intensivists and pharmacists at our institution for additional trials. We selected search terms from the keywords and MESH terms of previous surfactant trials and from the generic and brand names of commercially available surfactants. We imposed no language restrictions.

\section{Trial selection}

One of us screened the title (and abstract if required) of all citations retrieved. We selected citations for further evaluation if they reported the administration of at least one dose of surfactant to at least one child or if the title or abstract did not give enough information to make an assessment. Two reviewers independently reviewed all citations meeting criteria for further review and applied the inclusion criteria. Disagreements between reviewers were resolved by consensus in consultation with a third reviewer. We considered agreement between reviewers to be acceptable if the kappa value was greater than 0.8 .

\section{Quality assessment}

We used the following characteristics to assess the methodologic quality: allocation concealment (sealed envelopes or central randomization were considered adequate), blinding (which of the trial personnel and caregivers were blinded, and the methods used to ensure blinding), completeness of followup (assessed by the number of patients randomized for whom there were no outcomes), similarity of the groups at baseline (with respect to known prognostic factors: age, aetiology, severity of illness as measured by the Pediatric Risk of Mortality score, and immunosuppression), whether a standard or recommended strategy for mechanical ventilation was used, and whether a priori criteria for the use of co-interventions were used. Effective blinding of surfactant is challenging because of the large volumes of milky fluid administered, which can often be seen by caregivers in the patients' ventilator tubing or endotracheal tube, particularly during suctioning.

We pretested and refined the developed forms on two trials of surfactant therapy for adults, and clarified definitions based on feedback from the reviewers. Two reviewers then independently used these forms to abstract trial quality, blinded to the authors, the journal, the country of origin and the results. We resolved any disagreements by consensus in consultation with a third reviewer if needed.

\section{Data abstraction}

After pretesting and refining the forms on two trials of surfactant therapy in adults and clarifying definitions based on feedback from the reviewers, two reviewers then independently abstracted the data. Reviewers were only provided with a full-text version of the trials from which the introduction, conclusions and discussion were omitted and from which the author, journal and country of origin were deleted. We thereafter examined these sections of the reports for any missing data. We resolved any disagreements between reviewers by consensus in consultation with a third reviewer if needed. We asked the authors to supply data not included in the published reports. Two reviewers performed data entry in duplicate. 


\section{Statistical methods}

We quantitatively pooled the results of individual trials when possible. We expressed the treatment effect as a relative risk for dichotomous outcomes and as a weighted mean difference for continuous outcomes with 95\% confidence intervals. We considered effects statistically significant if $P<0.05$. A $z$ test was used to statistically test the estimates of treatment effect between groups [16]. We assessed heterogeneity among trials using the $l^{2}$ statistic, and considered an $l^{2}$ value greater than $50 \%$ to indicate substantial heterogeneity [17]. RevMan 4.2 software and a random effects model were used to perform the analyses [18]. We chose the random effects model because it gives a more conservative estimate of the precision of the treatment effects and because the true effect of the intervention probably varies given the different populations enrolled in these trials [19]. A subgroup analysis was planned based on the aetiology of respiratory failure (trials enrolling exclusively patients with respiratory syncytial virus (RSV)/ severe bronchiolitis compared with all other trials) if sufficient data were available, because these trials were likely to enrol a younger, more homogeneous, population with a lower predicted risk of mortality. We also planned sensitivity analysis based on methodological features of the included trials (trials reporting adequate allocation concealment compared with all other trials).

\section{Results}

\section{Trial flow}

We identified 742 unique citations, six of which met our inclusion criteria (Figure 1 outlines the reasons for exclusion). Most reports excluded enrolled neonates or were retrospective or uncontrolled in design. Chance corrected agreement was
Figure 1

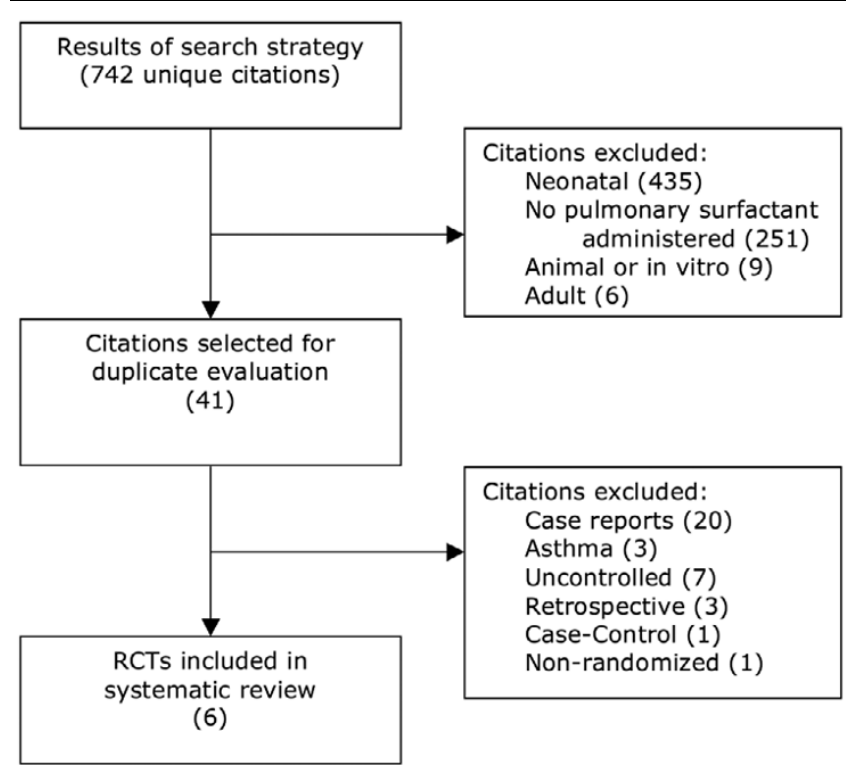

Flow diagram of included trials. RCTs, randomized controlled trials.

excellent $(\mathrm{kappa}=0.91,95 \%$ confidence interval $=0.73-$ 1.1).

\section{Methodologic quality of included trials}

Table 1 presents a complete description of our quality assessment. Only one trial did not report allocation concealment [20]. Although effective blinding of surfactant is challenging, two trials reported blinding of the PICU team $[12,20]$. The two

Table 1

Trial methodological quality

\begin{tabular}{|c|c|c|c|c|c|c|}
\hline Trial & $\begin{array}{l}\text { Allocation } \\
\text { concealment } \\
\text { reported? (Method } \\
\text { used) }\end{array}$ & $\begin{array}{l}\text { Who was reported to be } \\
\text { blinded? (Who } \\
\text { administered the } \\
\text { intervention?) }\end{array}$ & $\begin{array}{l}\text { Completeness of } \\
\text { follow-up reported?a }\end{array}$ & $\begin{array}{l}\text { Groups similar at } \\
\text { baseline?b }\end{array}$ & $\begin{array}{l}\text { Ventilation algorithm } \\
\text { described? }\end{array}$ & $\begin{array}{l}\text { Criteria for rescue } \\
\text { therapyc }\end{array}$ \\
\hline Luchetti, 1998 & $\begin{array}{l}\text { Yes (sealed } \\
\text { envelopes) }\end{array}$ & Not reported & Not reported & Yes & Yes & Not reported \\
\hline Willson, 1999 & $\begin{array}{l}\text { Yes (opaque sealed } \\
\text { envelopes) }\end{array}$ & Unblinded & $91 \%$ & $\begin{array}{l}\text { Lower PRISM scores } \\
\text { in control group ( } 9 \\
\text { versus 12) }\end{array}$ & Yes & No \\
\hline Tibby, 2000 & Not reported & $\begin{array}{l}\text { Care providers } \\
\text { (investigators not involved } \\
\text { in patient care) }\end{array}$ & Not reported & Yes & Yes & Not reported \\
\hline Luchetti, 2002 & $\begin{array}{l}\text { Yes (sealed } \\
\text { envelope) }\end{array}$ & $\begin{array}{l}\text { Outcome assessors } \\
\text { (investigators) }\end{array}$ & Not reported & Yes & Yes & No \\
\hline Moller, 2003 & $\begin{array}{l}\text { Yes (central } \\
\text { telephone) }\end{array}$ & Unblinded & $87 \%$ & Yes & Yes & Yes \\
\hline Willson, 2005 & $\begin{array}{l}\text { Yes (opaque sealed } \\
\text { envelopes) }\end{array}$ & $\begin{array}{l}\text { Care providers, } \\
\text { investigators (respiratory } \\
\text { therapist not involved in } \\
\text { patient care) }\end{array}$ & $100 \%$ & $\begin{array}{l}\text { More } \\
\text { immunosuppressed } \\
\text { in control group ( } 30 \\
\text { versus 22) }\end{array}$ & Yes & No \\
\hline
\end{tabular}

aPatients randomized but not included in the analysis. bPotentially clinically significant differences in age, aetiology, severity of illness (Pediatric Risk of Mortality (PRISM) score) and immunosuppression. ${ }^{c} A$ priori criteria for the use of extracorporeal membrane oxygenation, high-frequency oscillatory ventilation, nitric oxide and open-label surfactant. 
Table 2

\begin{tabular}{|c|c|c|c|c|c|c|c|}
\hline Trial & $\begin{array}{l}\text { Patient } \\
\text { populationa }\end{array}$ & $\begin{array}{l}\text { Number of } \\
\text { centres }\end{array}$ & $\begin{array}{l}\text { Surfactant } \\
\left(\text { dose }^{b}\right)\end{array}$ & Control & Primary outcome & $\begin{array}{l}\text { Duration of follow- } \\
\text { up }\end{array}$ & Funding source \\
\hline Luchetti, 1998 & $\begin{array}{l}\text { Severe } \\
\text { bronchiolitis }\end{array}$ & $\begin{array}{l}\text { Unclear, probably } \\
1\end{array}$ & $\begin{array}{l}\text { Poractant - } \\
\text { porcine } \\
(50 \mathrm{mg} / \mathrm{kg} \text { single } \\
\text { dose })\end{array}$ & None & Unclear & PICU discharge & Not reported \\
\hline Willson, 1999 & ARDS/ALI & 8 & $\begin{array}{l}\text { Calfactant - } \\
\text { bovine } \\
\left(2,800 \mathrm{mg} / \mathrm{m}^{2}\right. \\
\text { every } 12 \text { hours for } \\
1-4 \text { doses })\end{array}$ & None & Mortality & $\begin{array}{l}\text { Hospital } \\
\text { discharge }\end{array}$ & $\begin{array}{l}\text { Partial support by } \\
\text { surfactant } \\
\text { manufacturer }\end{array}$ \\
\hline Tibby, 2000 & $\begin{array}{l}\text { RSV-induced } \\
\text { respiratory failure }\end{array}$ & $\begin{array}{l}\text { Unclear, probably } \\
1\end{array}$ & $\begin{array}{l}\text { Beractant - } \\
\text { modified bovine } \\
(100 \mathrm{mg} / \mathrm{kg} \text { every } \\
24 \text { hours for } 2 \\
\text { doses) }\end{array}$ & Air placebo & $\begin{array}{l}\text { Indices of gas } \\
\text { exchange }\end{array}$ & $\begin{array}{l}\text { Hospital } \\
\text { discharge }\end{array}$ & Not reported \\
\hline Luchetti, 2002 & $\begin{array}{l}\text { RSV-induced } \\
\text { respiratory failure }\end{array}$ & 6 & $\begin{array}{l}\text { Poractant - } \\
\text { porcine } \\
(50 \mathrm{mg} / \mathrm{kg} \text { dose } \\
\text { every } 24 \text { hours for } \\
1-2 \text { doses })\end{array}$ & $\begin{array}{l}\text { Sedation and } \\
\text { manual ventilation }\end{array}$ & $\begin{array}{l}\text { Vent days and } \\
\text { PICU stay }\end{array}$ & PICU discharge & Not reported \\
\hline Moller, 2003 & ARDS & 19 & $\begin{array}{l}\text { Bovactant - } \\
\text { bovine } \\
\text { (100 } \mathrm{mg} / \mathrm{kg}, 1-2 \\
\text { doses within } 48 \\
\text { hours) }\end{array}$ & None & $\begin{array}{l}\text { Change in } \mathrm{PaO}_{2} / \\
\mathrm{FiO}_{2} \text { at } 48 \text { hours }\end{array}$ & 30 days & $\begin{array}{l}\text { Surfactant } \\
\text { manufacturer }\end{array}$ \\
\hline Willson, 2005 & ARDS/ALI & 21 & $\begin{array}{l}\text { Calfactant - } \\
\text { bovine } \\
\left(2,800 \mathrm{mg} / \mathrm{m}^{2}-\text { if }\right. \\
<10 \mathrm{~kg}, 105 \mathrm{mg} / \\
\mathrm{kg}-\text { every } 12 \\
\text { hours for } 1-2 \\
\text { doses) }\end{array}$ & Air placebo & $\begin{array}{l}\text { Ventilator-free } \\
\text { days at day } 28\end{array}$ & $\begin{array}{l}\text { Hospital } \\
\text { discharge }\end{array}$ & $\begin{array}{l}\text { Surfactant } \\
\text { manufacturer }\end{array}$ \\
\hline
\end{tabular}

ALI, acute lung injury; ARDS, acute respiratory distress syndrome; PICU, paediatric intensive care unit; RSV, respiratory syncytial virus. aSee Additional file 1 for the complete inclusion criteria and exclusion criteria. bDose expressed as $\mathrm{mg} / \mathrm{kg}$ phospholipids.

groups were generally well matched in terms of baseline characteristics in most trials. The most significant imbalance was the numerically higher number of immunosuppressed patients in the placebo group. These patients had higher mortality (56\%) than the immunocompetent group (13\%). The authors attempted to adjust for this imbalance with logistic regression, which suggested that the treatment effect seemed to be relatively consistent between the two groups [12]. Only one trial reported a priori criteria for rescue therapy [13].

\section{Description of included trials}

Table 2 describes the included trials. Three trials enrolled exclusively infants with RSV-induced respiratory failure $[20,21]$ or with severe bronchiolitis [22]. The remaining three trials enrolled a heterogeneous group of patients with ARDS or ALI $[12,23,24]$. While the individual treatment protocols varied, all trials used comparable doses $(50-100 \mathrm{mg} / \mathrm{kg}$ phospholipids) of natural or modified natural surfactants and each patient typically received one or two doses. A variety of interventions were used in the control groups: no intervention, air placebo or similar sedation and ventilation manoeuvres without a placebo. Although one study [20] used a modified natural surfactant, all the products used contained surfactant proteins B and C. All studies administered surfactant early in the course of respiratory failure; most patients were treated within 12-48 hours of requiring mechanical ventilation.

The baseline characteristics of the patients are presented in Table 3. While there was significant heterogeneity among and within trials with respect to age and cause of respiratory failure, we considered the initial Pediatric Risk of Mortality scores and the initial $\mathrm{PaO}_{2} / \mathrm{FiO}_{2}$ ratios to be clinically comparable.

\section{Primary outcome: mortality}

Mortality data were available for all six trials, randomizing 311 patients and reporting data for 305 patients. There were no deaths reported in the three RSV/severe bronchiolitis trials; thus our estimate is based on three trials randomizing 232 patients, 64 of whom died. In the pooled analysis, surfactant was associated with significantly lower mortality (relative risk $=0.7,95 \%$ confidence interval $=0.4-0.97, P=0.04)$. There was no evidence of heterogeneity $(/ 2=0 \%)$ (Figure 2 ).

\section{Secondary outcomes}

Ventilator-free days to day 28

The number of ventilator-free days to day 28 was available for six trials randomizing 311 patients and reporting data for 305 patients. In the pooled analysis, surfactant was associated with significantly more ventilator-free days (weighted mean dif- 
Table 3

\begin{tabular}{|c|c|c|c|c|c|c|}
\hline \multirow{2}{*}{$\begin{array}{l}\text { Trial } \\
\text { Luchetti, } 1998\end{array}$} & \multicolumn{2}{|c|}{ Aetiology of respiratory failure ${ }^{a}$} & \multirow{2}{*}{$\begin{array}{l}\text { Treatment group } \\
\text { Surfactant }\end{array}$} & \multirow{2}{*}{$\begin{array}{l}\text { Age (years) } \\
0.87(0.15)\end{array}$} & \multirow{2}{*}{$\frac{\text { Initial } \mathrm{PaO}_{2} / \mathrm{FiO}_{2}}{118(15.8)}$} & \multirow{2}{*}{$\begin{array}{l}\text { PRISM score } \\
\text { Not reported }\end{array}$} \\
\hline & $\begin{array}{l}\text { Bronchiolitis } \\
\text { Pneumonia }\end{array}$ & $100 \%$ & & & & \\
\hline & & $50 \%$ & Placebo & $0.93(0.17)$ & $122(12.0)$ & Not reported \\
\hline \multirow[t]{6}{*}{ Willson, 1999} & ARDS & $31 \%$ & & & & \\
\hline & Pneumonia & $26 \%$ & Surfactant & $5.0(5.34)$ & $102(53)$ & $12(6)$ \\
\hline & RSV & $17 \%$ & Placebo & $4.5(5.66)$ & $105(42)$ & $9(4)$ \\
\hline & Near-drowning & $7 \%$ & & & & \\
\hline & Sepsis & $7 \%$ & & & & \\
\hline & Other & $14 \%$ & & & & \\
\hline \multirow[t]{2}{*}{ Tibby, 2000} & RSV & $100 \%$ & Surfactant & $0.17(0.14,0.27)^{b}$ & $146(134,171)^{b}$ & $11(11,15)^{b}$ \\
\hline & & & Placebo & $0.13(0.09,0.18)^{b}$ & $160(106,205)^{b}$ & $13(11,15)^{b}$ \\
\hline \multirow[t]{2}{*}{ Luchetti, 2002} & RSV & $100 \%$ & Surfactant & $0.73(0.675)$ & Not reported & $12(1.1)$ \\
\hline & Pneumonia & $45 \%$ & Placebo & $0.62(0.542)$ & Not reported & $12(1.2)$ \\
\hline \multirow[t]{2}{*}{ Moller, 2003} & Pneumonia & $68 \%$ & Surfactant & 3.5 (range 0-13) & $71(13.7)$ & $12(6.5)$ \\
\hline & Sepsis & $32 \%$ & Placebo & 4.5 (range $(0-12)$ & $64(16.2)$ & $11(4.5)$ \\
\hline \multirow[t]{5}{*}{ Willson, 2005} & ARDS or sepsis & $35 \%$ & Surfactant & $7.2(6.4)$ & $128(54)$ & $15(9.4)$ \\
\hline & Pneumonia & $42 \%$ & Placebo & $6.7(6.4)$ & $126(73)$ & $14(7.9)$ \\
\hline & RSV & $7 \%$ & & & & \\
\hline & Near-drowning & $5 \%$ & & & & \\
\hline & Other & $11 \%$ & & & & \\
\hline
\end{tabular}

Values expressed as the mean (standard deviation) unless otherwise indicated. ARDS: acute respiratory distress syndrome; PRISM, Pediatric Risk of Mortality; RSV: respiratory syncytial virus. aTotals may be greater than $100 \%$ due to rounding and because multiple aetiologies were reported for some patients. bMedian (interquartile range).

ference $=2.5$ days, $95 \%$ confidence interval $=0.3-4.6$ days, $P=0.02$ ) (Figure 3).

\section{Duration of mechanical ventilation}

The duration of mechanical ventilation was available for six trials randomizing 311 patients and reporting data for 305 patients. In the pooled analysis, surfactant was associated with a significantly shorter duration of mechanical ventilation (weighted mean difference $=2.3$ days, 95\% confidence interval $=0.1-4.4$ days, $P=0.04$ ) (Figure 4).

\section{Duration of PICU stay}

The duration of PICU stay was available for five trials randomizing 273 patients and reporting data for 272 patients. In the pooled analysis, surfactant was associated with a shortened duration of PICU stay (weighted mean difference $=2.6$ days, $95 \%$ confidence interval $=0.02-5.2$ days, $P=0.05$ ), but this difference was not statistically significant (Figure 5).

Use of rescue therapy

Data on the use of rescue therapy were available for six trials randomizing 311 patients and reporting data for 305 patients.
In the pooled analysis, the surfactant was associated with a significantly lower use of rescue therapy (relative risk $=0.4$, $95 \%$ confidence interval $=0.3-0.7, P<0.0001)$. There was no evidence of heterogeneity $(/ 2=0 \%)$. This summary estimate should be interpreted with caution as only one trial reported a protocol for initiating rescue therapy. The decision to use a rescue therapy, particularly an open-label surfactant, may be influenced by knowledge of the patient's allocation; furthermore, only two trials reported blinded caregivers and the methods used to ensure blinding may not be adequate.

\section{Adverse events}

Surfactant therapy was well tolerated (see Table 4), but only three of the trials reported any definitions or a priori criteria or of collecting adverse events $[12,21,23]$. Transient hypotension and transient hypoxia were the most commonly reported adverse events in the largest trial. These responded to a brief adjustment in ventilation, to a slowing of the rate of surfactant administration or to fluid administration. There was no difference in the incidence of air leaks in the two trials that reported this outcome. No patient was withdrawn from any of the trials because of adverse events. We did not pool the data 
Figure 2

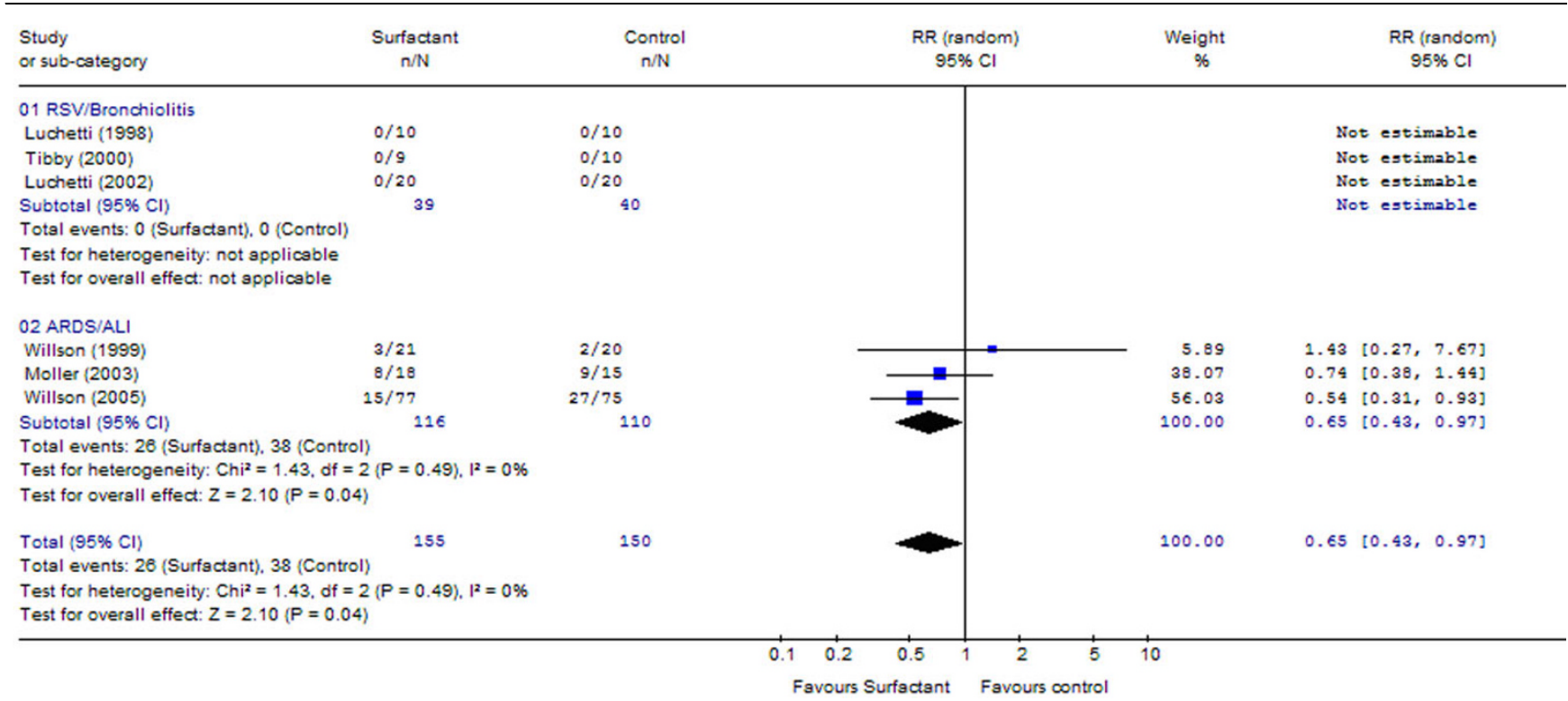

Meta-analysis of trials of surfactant in children with acute respiratory failure: Mortality. ALI, acute lung injury; ARDS, acute respiratory distress syndrome; $95 \% \mathrm{Cl}, 95 \%$ confidence interval; RR, relative risk; RSV, respiratory syncytial virus.

on adverse events associated with the trial interventions from the six trials because of the inconsistent manner in which the events were documented and reported.

\section{Subgroup analysis}

The effect of surfactant on ventilator-free days, the duration of mechanical ventilation and the duration of PICU stay was not significantly different when we compared the three trials that enrolled exclusively patients with RSV/severe bronchiolitis with the three other trials (Table 5). A 100\% survival in the bronchiolitis trials subgroup precludes formal subgroup analysis for the primary outcome of mortality.

\section{Sensitivity analysis}

All but one of the included trials reported adequate allocation concealment (defined as sealed envelopes or central telephone randomization). Since there were no deaths in this trial we could not assess the effect of inadequate allocation concealment on mortality. Pooling the five remaining trials did not change the direction of the effect and did not significantly

Figure 3

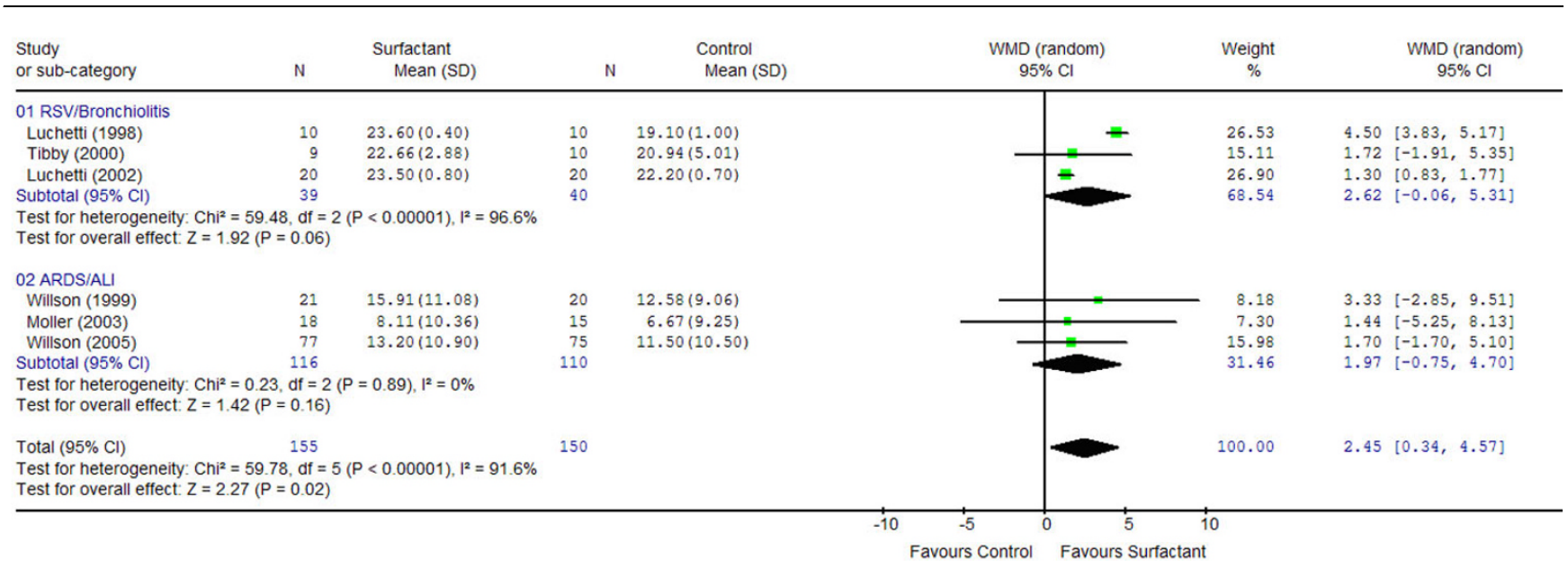

Meta-analysis of trials of surfactant in children with acute respiratory failure: Ventilator-free days. ALI, acute lung injury; ARDS, acute respiratory distress syndrome; 95\% Cl, 95\% confidence interval; RSV, respiratory syncytial virus; SD, standard deviation; WMD, weighted mean difference. 
Figure 4

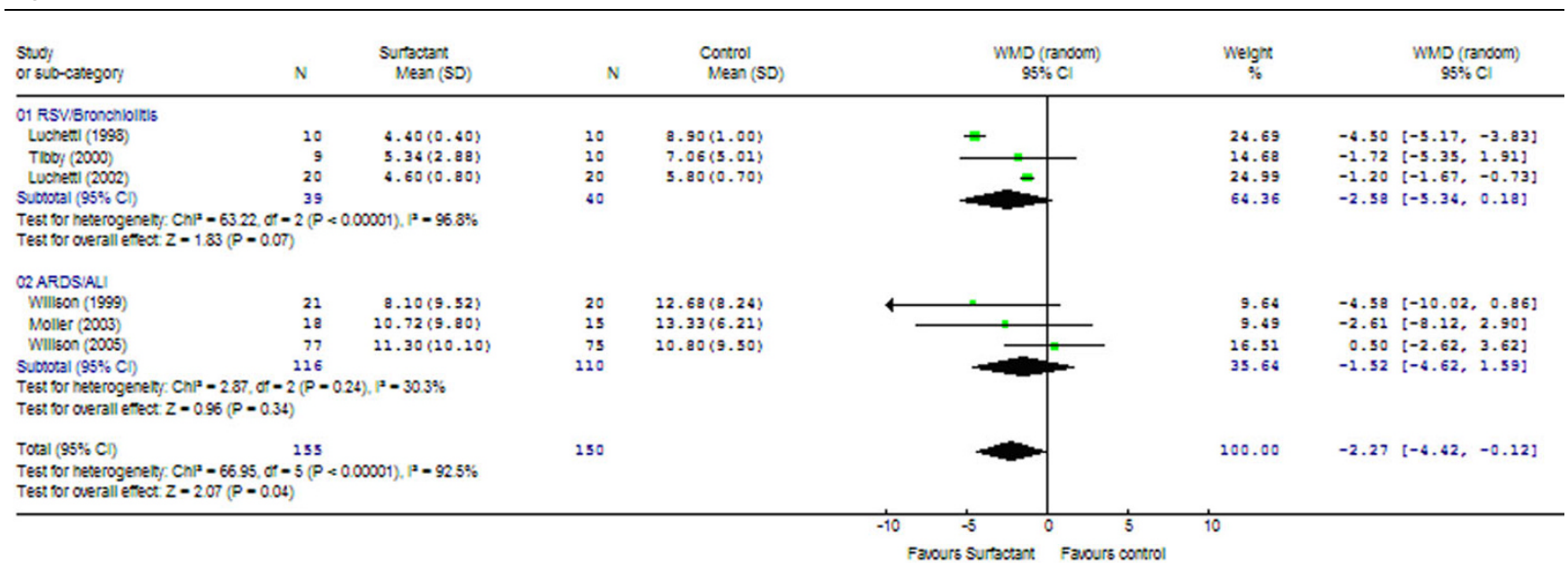

Meta-analysis of trials of surfactant in children with acute respiratory failure: Duration of mechanical ventilation. ALI, acute lung injury; ARDS, acute respiratory distress syndrome; $95 \% \mathrm{Cl}, 95 \%$ confidence interval; RSV, respiratory syncytial virus; SD, standard deviation; WMD, weighted mean difference.

change the point estimates for the secondary outcomes of ventilator-free days, duration of ventilation or duration of PICU stay (Table 6).

\section{Discussion}

In the present systematic review and meta-analysis of the effect of surfactant for critically ill children with acute respiratory failure we found that surfactant therapy significantly reduced our primary outcome of mortality. Surfactant was associated with more ventilator-free days, with decreased duration of ventilation and with less use of rescue therapy as compared with standard therapy. There was no significant difference in the duration of PICU stay. Surfactant therapy was well tolerated; while transient hypoxia and hypotension were reported during surfactant administration, no study reported any serious adverse events. The patients enrolled in these trials are representative of the heterogeneous group of children with early, severe acute respiratory failure that is seen in clinical practice. These patients had similar severity of illness scores and a similar degree of respiratory failure (as measured by Pediatric Risk of Mortality scores and $\mathrm{PaO}_{2}: \mathrm{FiO}_{2}$ ratios).

The heterogeneity of results for our primary outcome of mortality was low. The presence of significant heterogeneity reduces the strength of inferences we can make regarding the effect of surfactant on the secondary outcomes of ventilator-free days,

Figure 5

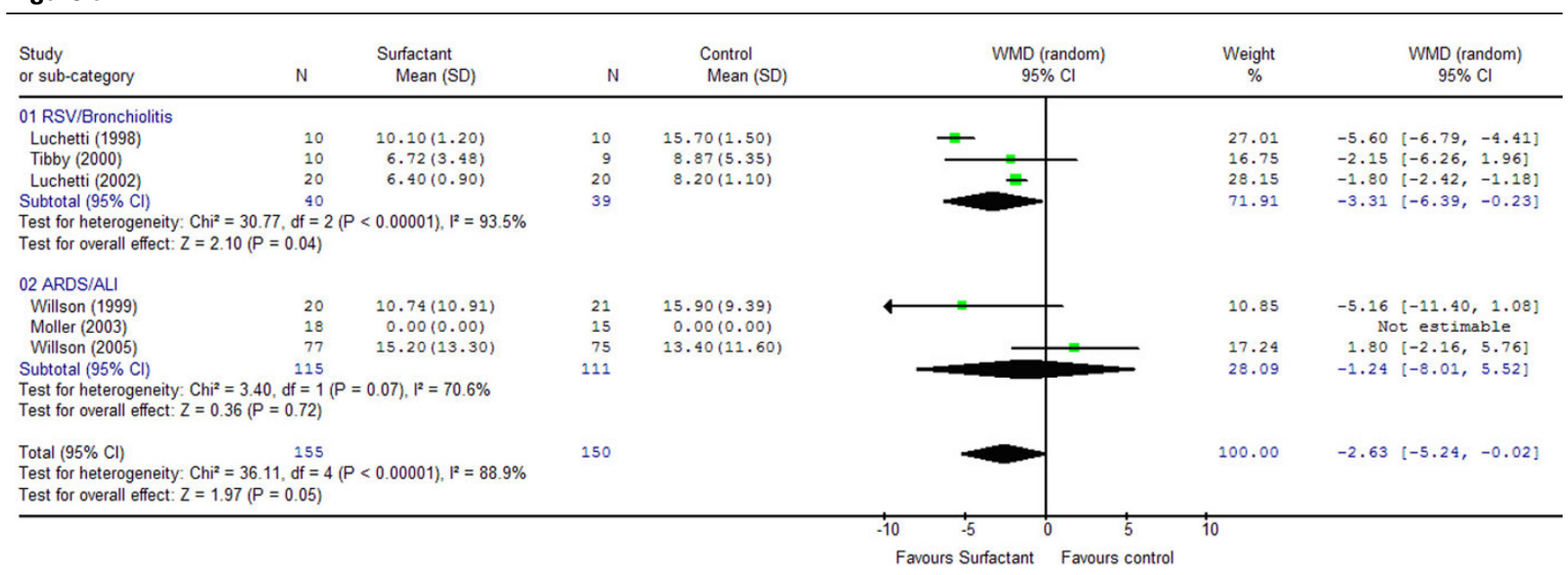

Meta-analysis of trials of surfactant in children with acute respiratory failure: Duration of PICU stay. ALI, acute lung injury; ARDS, acute respiratory distress syndrome; $95 \% \mathrm{Cl}$, 95\% confidence interval; PICU, paediatric intensive care unit; RSV, respiratory syncytial virus; SD, standard deviation; WMD, weighted mean difference. 
Critical Care Vol 11 No 3 Duffett et al.

Table 4

Reported adverse events

\begin{tabular}{|c|c|c|}
\hline \multirow[t]{2}{*}{ Trial } & \multicolumn{2}{|l|}{ Adverse events reported } \\
\hline & Surfactant $(n=157)$ & Control $(n=150)$ \\
\hline \multirow[t]{2}{*}{ Luchetti, 1998} & 'No adverse haemodynamic effects were noted' & 'No complications were reported in either group' \\
\hline & 'No complications were reported in either group' & \\
\hline \multirow[t]{3}{*}{ Willson, 1999} & One with transient bronchospam & One with air leak \\
\hline & Two with air leaks & $\begin{array}{l}\text { One with air leak and pulmonary interstitial } \\
\text { emphysema }\end{array}$ \\
\hline & One with pulmonary interstitial emphysema & One plugged endotracheal tube \\
\hline Tibby, 2000 & 'No complications were noted after surfactant administration' & Not reported \\
\hline Luchetti, 2002 & $\begin{array}{l}\text { 'No complications due to the treatment were observed in the surfactant- } \\
\text { treated group' }\end{array}$ & $\begin{array}{l}\text { '... no complications were found in the control } \\
\text { group' }\end{array}$ \\
\hline Moller, 2003 & $\begin{array}{l}\text { 'No treatment associated adverse events were observed in the surfactant } \\
\text { group; however, the expected risk of intermittent obstruction of the } \\
\text { endotracheal tube with a short time deterioration on oxygenation was } \\
\text { observed in } 3 \text { patients' }\end{array}$ & Not reported \\
\hline \multirow[t]{4}{*}{ Willson, 2005} & Hypotension $9 \%$ & Hypotension $1 \%$ \\
\hline & Transient hypoxia $12 \%$ & Transient hypoxia 3\% \\
\hline & Air leaks $13 \%$ & Air leaks $16 \%$ \\
\hline & Nosocomial pneumonia $6 \%$ & Nosocomial pneumonia $11 \%$ \\
\hline
\end{tabular}

duration of ventilation and duration of PICU stay. Separately pooling the trials that exclusively enrolled patients with RSV/ severe bronchiolitis and those enrolling patients with ARDS/ $A L I$ from a variety of causes did not significantly reduce the heterogeneity. Changing ventilation strategies and the use of a variety of natural and modified natural surfactants may have increased the heterogeneity of our results. Ventilation strategies, such as the use of lower tidal volumes and earlier use of high-frequency oscillatory ventilation, have evolved significantly in the 10-year span over which the included trials were conducted [25-27]. The surfactants used in the included trials were all natural or modified natural surfactants; however, these surfactants may have slightly different effects on oxygenation and compliance due to the differences in phospholipid and surfactant protein composition, which may have influenced individual study results.

Table 5

\begin{tabular}{lll}
\hline Subgroup analysis & & \\
\hline Outcome & Bronchiolitis trials & All other trials \\
\hline Mortality & Unable to assess & \\
Ventilator-free days & & 2.0 \\
$\quad$ Weighted mean difference (days) & 2.6 & -0.8 to 4.7 \\
$\quad 95 \%$ confidence interval & -0.1 to 5.3 & 1.5 \\
Duration of mechanical ventilation & & -1.6 to 4.6 \\
$\quad$ Weighted mean difference (days) & 2.6 & 0.76 \\
$95 \%$ confidence interval & -0.1 to 5.3 & 1.2 \\
Duration of paediatric intensive care unit stay & & -5.5 to 8.0 \\
Weighted mean difference (days) & 3.3 & 0.60 \\
$95 \%$ confidence interval & 0.2 to 6.4 & 0.58
\end{tabular}


Table 6

\begin{tabular}{|c|c|c|c|}
\hline Outcome & Trials reporting adequate allocation concealment & All other trials & $P$ value \\
\hline Mortality & Unable to assess & & \\
\hline Ventilator-free days & & & 0.68 \\
\hline Weighted mean difference (days) & 2.6 & 1.7 & \\
\hline $95 \%$ confidence interval & 0.3 to 4.7 & -1.9 to 5.4 & \\
\hline Duration of mechanical ventilation & & & 0.76 \\
\hline Weighted mean difference (days) & 2.4 & 1.7 & \\
\hline $95 \%$ confidence interval & -0.01 to 4.7 & -1.9 to 5.4 & \\
\hline Duration of paediatric intensive care unit stay & & & 0.85 \\
\hline Weighted mean difference (days) & 2.7 & 2.2 & \\
\hline $95 \%$ confidence interval & -0.3 to 5.7 & -2.0 to 6.3 & \\
\hline
\end{tabular}

The strengths of the present review include a comprehensive search strategy, broad inclusion criteria (resulting in a representative, heterogeneous population) and abstraction of clinically important outcomes in duplicate, independently blinded to information that may bias evaluation. The strength of the inference we can make from our subgroup analysis is limited because we were unable to extract all subgroup data from these trials. Access to individual patient data would allow better examination of the treatment effect in subgroups of patients and would facilitate further exploration of possible causes of heterogeneity.

We found that mortality was very different between the trials that exclusively enrolled patients with RSV/severe bronchiolitis and those that enrolled patients with ARDS/ALI from a variety of causes. We pooled the results because both conditions result in abnormal surfactant function and because of the substantial overlap between the two groups; up to $17 \%$ of children in the ARDS/ALI trials had RSV and up to $50 \%$ of the children in some bronchiolitis studies also had pneumonia.

The reduction in mortality and the increased ventilator-free days have important implications as very few trials in paediatric critical care suggest a favourable impact on mortality [28]. The present review suggests that surfactant could be an important adjunct in the management of paediatric respiratory failure. Uncertainty exists, however, about the reproducibility of treatment effects generated from relatively small unblinded trials; questions remain about adverse affects, which may be undetected or under-reported in this literature. Also, a large proportion of patients and events are reported in one trial [12]. Furthermore, issues of the optimal dose and the timing of administration, and which patients are most likely to derive benefit, should be studied in further adequately powered multicentre trials. The Pediatric Acute Lung Injury and Sepsis Investigators network is planning a large rigorous randomized trial enrolling children with acute hypoxemic respiratory failure to address these issues.

\section{Conclusion}

Surfactant use decreased mortality, was associated with more ventilator-free days and reduced the duration of ventilation. No serious adverse events were reported. Most trials enrolled small numbers of children, and further well-designed and adequately powered multicentre trials are therefore required.

\section{Key messages}

- Surfactant decreased mortality in a heterogeneous population of children with acute respiratory failure.

- Surfactant was associated with more ventilator-free days and a reduced duration of ventilation.

- No serious adverse events were reported.

- Further well-designed and adequately powered multicentre trials are required.

\section{Competing interests}

The authors declare that they have no competing interests.

\section{Authors' contributions}

$\mathrm{MD}$ conceived of this review. MD, KC, VN and DJC participated in the design. MD and $\mathrm{VN}$ extracted data and assessed the quality of the included studies. MD, KC, DJC and AR helped to draft the manuscript. All authors read and approved the final manuscript. 


\section{Additional files}

The following Additional files are available online:

\section{Additional file 1}

A Word file containing a table listing individual trial inclusion criteria and exclusion criteria.

See http://www.biomedcentral.com/content/ supplementary/cc5944-S1.doc

\section{Acknowledgements}

The authors would like to acknowledge the authors of the primary trials (Dr Marco Luchetti, Dr Jens Möller, Dr Shane Tibby and Dr Douglas Willson) for providing additional information or clarification. Thanks to John Duffett for reviewing the citations and for data entry.

\section{References}

1. Randolph AG, Meert KL, O'Neil ME, Hanson JH, Luckett PM, Arnold JH, Gedeit RG, Cox PN, Roberts JS, Venkataraman ST, et al: The feasibility of conducting clinical trials in infants and children with acute respiratory failure. Am J Respir Crit Care Med 2003, 167:1334-1340.

2. Royall JA, Levin DL: Adult respiratory distress syndrome in pediatric patients. I. Clinical aspects, pathophysiology, pathology, and mechanisms of lung injury. J Pediatr 1988, 112:169-180.

3. Skelton R, Holland P, Darowski M, Chetcuti PA, Morgan LW, Harwood JL: Abnormal surfactant composition and activity in severe bronchiolitis. Acta Paediatr 1999, 88:942-946.

4. Dargaville PA, South M, McDougall PN: Surfactant abnormalities in infants with severe viral bronchiolitis. Arch Dis Child 1996, 75:133-136.

5. Long W, Corbet A, Cotton R, Courtney S, McGuiness G, Walter $D$, Watts J, Smyth J, Bard H, Chernick V: A controlled trial of synthetic surfactant in infants weighing $1250 \mathrm{~g}$ or more with respiratory distress syndrome. The American Exosurf Neonatal Study Group I, and the Canadian Exosurf Neonatal Study Group. N Engl J Med 1991, 325:1696-1703.

6. Anzueto A, Baughman RP, Guntupalli KK, Weg JG, Wiedemann HP, Raventos AA, Lemaire F, Long W, Zaccardelli DS, Pattishall EN: Aerosolized surfactant in adults with sepsis-induced acute respiratory distress syndrome. Exosurf Acute Respiratory Distress Syndrome Sepsis Study Group. N Engl J Med 1996, 334:1417-1421.

7. Gregory TJ, Steinberg KP, Spragg R, Gadek JE, Hyers TM, Longmore WJ, Moxley MA, Cai GZ, Hite RD, Smith RM, et al:: Bovine surfactant therapy for patients with acute respiratory distress syndrome. Am J Respir Crit Care Med 1997, 155:1309-1315.

8. Spragg RG, Lewis JF, Wurst W, Hafner D, Baughman RP, Wewers MD, Marsh JJ: Treatment of acute respiratory distress syndrome with recombinant surfactant protein $\mathrm{C}$ surfactant. $\mathrm{Am} \mathrm{J}$ Respir Crit Care Med 2003, 167:1562-1566.

9. Weg JG, Balk RA, Tharratt RS, Jenkinson SG, Shah JB, Zaccardelli $D$, Horton J, Pattishall EN: Safety and potential efficacy of an aerosolized surfactant in human sepsis-induced adult respiratory distress syndrome. JAMA 1994, 272:1433-1438.

10. Lewis JF, Dhillon JS, Singh RN, Johnson CC, Frewen TC: Exogenous surfactant therapy for pediatric patients with the acute respiratory distress syndrome. Can Respir J 1997, 4:21-26.

11. Willson DF, Jin Hua J, Bauman LA, Zaritsky A, Craft H, Dockery K, Conrad $D$, Dalton $\mathrm{H}$ : Calf's lung surfactant extract in acute hypoxemic respiratory failure in children. Crit Care Med 1996, 24:1316-1322.

12. Willson DF, Thomas NJ, Markovitz BP, Bauman LA, DiCarlo JV Pon S, Jacobs BR, Jefferson LS, Conaway MR, Egan EA: Effect of exogenous surfactant (calfactant) in pediatric acute lung injury: a randomized controlled trial. JAMA 2005, 293:470-476

13. Moller JC, Schaible T, Roll C, Schiffmann JH, Bindl L, Schrod L, Reiss I, Kohl M, Demirakca S, Hentschel R, et al:: Treatment with bovine surfactant in severe acute respiratory distress syndrome in children: a randomized multicenter study. Intensive Care Med 2003, 29:437-446.

14. Davison C, Ventre KM, Luchetti M, Randolph AG: Efficacy of interventions for bronchiolitis in critically ill infants: a systematic review and meta-analysis. Pediatr Crit Care Med 2004 5:482-489

15. Schoenfeld DA, Bernard GR, Network A: Statistical evaluation of ventilator-free days as an efficacy measure in clinical trials of treatments for acute respiratory distress syndrome. Crit Care Med 2002, 30:1772-1777.

16. Fleiss JL: The statistical basis of meta-analysis. Stat Methods Med Res 1993, 2:121-145.

17. Higgins JPT, Thompson SG: Quantifying heterogeneity in a meta-analysis. Stat Med 2002, 21:1539-1558.

18. RevMan Analyses 1.0 for Windows in Review Manager [RevMan] 4.2 Copenhagen: The Nordic Cochrane Centre, The Cochrane Collaboration; 2003.

19. DerSimonian R, Laird N: Meta-analysis in clinical trials. Control Clin Trials 1986, 7:177-188.

20. Tibby SM, Hatherill M, Wright SM, Wilson P, Postle AD, Murdoch IA: Exogenous surfactant supplementation in infants with respiratory syncytial virus bronchiolitis. Am J Respir Crit Care Med 2000, 162:1251-1256.

21. Luchetti M, Ferrero F, Gallini C, Natale A, Pigna A, Tortorolo L, Marraro G: Multicenter, randomized, controlled study of porcine surfactant in severe respiratory syncytial virus-induced respiratory failure. Pediatr Crit Care Med 2002, 3:261-268.

22. Luchetti M, Casiraghi G, Valsecchi R, Galassini E, Marraro G: Porcine-derived surfactant treatment of severe bronchiolitis. Acta Anaesthesiol Scand 1998, 42:805-810.

23. Willson DF, Zaritsky A, Bauman LA, Dockery K, James RL, Conrad D, Craft H, Novotny WE, Egan EA, Dalton H: Instillation of calf lung surfactant extract (calfactant) is beneficial in pediatric acute hypoxemic respiratory failure. Crit Care Med 1999, 27:188-195

24. Moller JC, Schaible T, Roll C, Schiffmann JH, Bindl L, Schrod L Reiss I, Kohl M, Demirakca S, Hentschel R, et al.: Treatment with bovine surfactant in severe acute respiratory distress syndrome in children: a randomized multicenter study. Intensive Care Med 2003, 29:437-446.

25. The Acute Respiratory Distress Syndrome Network: Ventilation with lower tidal volumes as compared with traditional tidal volumes for acute lung injury and the acute respiratory distress syndrome. N Engl J Med 2000, 342:1301-1308.

26. Arnold JH, Anas NG, Luckett P, Cheifetz IM, Reyes G, Newth CJ, Kocis KC, Heidemann SM, Hanson JH, Brogan TV, Bohn DJ: High-frequency oscillatory ventilation in pediatric respiratory failure: a multicenter experience. Crit Care Med 2000, 28:3913-3919.

27. Arnold JH, Hanson JH, Toro-Figuero LO, Gutierrez J, Berens RJ, Anglin DL: Prospective, randomized comparison of high-frequency oscillatory ventilation and conventional mechanical ventilation in pediatric respiratory failure. Crit Care Med 1994, 22:1530-1539.

28. Curley MA, Zimmerman JJ: Alternative outcome measures for pediatric clinical sepsis trials. Pediatr Crit Care Med 2005, 6:S150-S156. 